\title{
Predation upon the oblique-banded leafroller, Choristoneura rosaceana (Lepidoptera: Tortricidae), by two aphidophagous coccinellids (Coleoptera: Coccinellidae) in the presence and absence of aphids
}

\author{
Éric LUCAS ${ }^{1}$, Sophie DEMOUGEOT ${ }^{1}$, Charles VINCENT $^{2 *}$ and Daniel CODERRE ${ }^{1}$ \\ ${ }^{1}$ Département des Sciences Biologiques, Université du Québec à Montréal, C.P. 8888 Succ. Centre-ville, Montréal, QC, Canada \\ H3C3P8; e-mails: lucas.eric@uqam.ca, coderre.d@uqam.ca \\ ${ }^{2}$ Horticultural Research and Development Center, Agriculture and Agri-Food Canada, 430, Gouin Blvd., Saint-Jean-sur-Richelieu, \\ QC, Canada J3B 3E6; e-mail: vincentch@agr.gc.ca
}

Key words. Harmonia axyridis, Coccinella septempunctata, Choristoneura rosaceana, Aphis pomi, biological control, predation, voracity, feeding preference, Coccinellidae

\begin{abstract}
Our goal has been to determine the effect of the presence of aphids on voracity (measured as number of prey eaten and biomass consumed) of Coccinella septempunctata L. and Harmonia axyridis Pallas (Coleoptera: Coccinellidae) feeding upon the oblique-banded leafroller, Choristoneura rosaceana (Harris) (Lepidoptera: Tortricidae). For each coccinellid predator, treatments using a single prey species, with either 30 first instar C. rosaceana or 100 third instars Aphis pomi DeGeer (Hemiptera: Aphididae), were compared with two-prey treatments in which the two prey species were present simultaneously. For both predators, the total number of prey killed (total prey species pooled) and the total biomass consumed were significantly higher when both prey were present than in single-prey treatments. The voracity of $C$. septempunctata on $C$. rosaceana larvae was not affected by adding $A$. pomi, whereas that of $H$. axyridis declined; the voracity of both predators on $A$. pomi increased when $C$. rosaceana larvae were added. The preference for the aphids over C. rosaceana was confirmed for both coccinellid species.
\end{abstract}

\section{INTRODUCTION}

The oblique-banded leafroller, Choristoneura rosaceana (Harris) (Lepidoptera: Tortricidae), feeds on a wide range of plant species including rose (Rosa spp.), dewberry (Rubus flagellaris L.), raspberry (Rubus idaeus L.), blueberry (Vaccinium corymbosum L.), apple (Malus domestica Borkh.), peach (Prunus persica Botsch), pear (Pyrus communis L.), cherry (Prunus avium L.), European hazel (Corylus avellana L.), pistachio (Pistacia vera L.), and forest trees (Chapman \& Lienk, 1971). In apple orchards, outbreaks have become more severe during the last 10-15 years in the United States and Canada, as $C$. rosaceana can damage apple trees seriously by attacking floral parts, fruit and leaves (Reissig, 1978). $C$. rosaceana became resistant to several insecticides registered in the USA (Reissig, 1978; Reissig et al., 1986) and Canada (Carrière et al., 1994; Smirle et al., 1998; Pree et al., 2001), necessitating the investigation of biological control methods that have radically different modes of action.

Among the aphidophagous coccinellid (Coleoptera: Coccinellidae) species found in orchards of eastern Canada (Tourneur et al., 1992), the seven spotted ladybeetle, Coccinella septempunctata L., and the asiatic ladybeetle, Harmonia axyridis Pallas, are the most common. They constitute potential biocontrol agents, owing to their ubiquity and competitive abilities. C. septempunctata is a voracious predator that can attack ca. 100 prey species including aphids, psyllids, coccids, thrips, leaf beetles and lepidopteran larvae (Iablokoff-Khnzorian, 1982; Kring et al., 1985; Kareiva, 1987; Horn, 1991). It is abundant in apple orchards of North America, including Michigan (Maredia et al., 1992) and Quebec (Tourneur et al., 1992). H. axyridis has been introduced to the United States (Chapin \& Brou, 1991; Tedders \& Schaefer, 1994) and became established in Canada in 1994 (Coderre et al., 1995). In Europe, H. axyridis is used to control aphid populations in orchards (Ongagna et al., 1993). H. axyridis is reported to be one of the most polyphagous coccinellid species (Hodek, 1996; Lucas et al., 1997, 1998b).

Both coccinellid species have been reported to attack lepidopteran prey (Iablokoff-Khnzorian, 1982; Horn, 1991; Mohan et al., 1991) and may have potential as natural enemies of the oblique-banded leafroller. However, both species belong to the aphidophagous coccinellid group and prey mainly on aphids. Predators may respond to the presence of a second prey species in different ways: 1) they may have a strong preference for one prey species and concentrate their efforts on this prey even when both prey are present or, 2) they may have no preference and attack any prey of whatever species is encountered or, 3) they may concentrate their attacks on the commonest prey and switch from one prey to another according to their respective densities (Murdoch \& Marks, 1973). The type of response may determine the potential efficiency of any biological control program because the presence of aphids may affect the predation efficacy of the ladybeetles against the leafroller.

\footnotetext{
* Corresponding author.
} 
The apple aphid, Aphis pomi DeGeer (Hemiptera: Aphididae), is a major pest in most commercial orchards and some of its populations have become resistant to a number of insecticides in the USA (Carroll \& Hoyt, 1984). Under favorable conditions, and due to its parthenogenic development (Dixon, 1985), the populations quickly can exceed economic thresholds and cause serious damage (Carroll \& Hoyt, 1984). A. pomi is preyed upon by both $C$. septempunctata (Iablokoff-Khnzorian, 1982 ) and $H$. axyridis (Hukusima \& Kamei, 1970) and is encountered in apple orchards at the same time as $C$. rosaceana. Both $A$. pomi and $C$. rosaceana are also encountered at the same time in the field during July and August in Quebec (Chouinard et al., 2000).

Our objective was to determine how the presence of the apple aphid affects the predation efficacy of $C$. septempunctata and $H$. axyridis on the obliquebanded leafroller. The voracity of both predators was evaluated using first instar $C$. rosaceana in the presence and absence of third instar A. pomi. Owing to their aphidophagous habits, it was expected that predation on the leafroller might be reduced in the presence of aphids.

\section{MATERIALS AND METHODS}

Insects. Overwintered Choristoneura rosaceana larvae were collected in a commercial apple orchard at Saint-Joseph-du-Lac

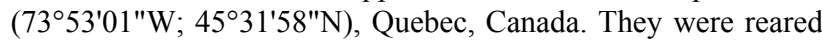
on an artificial diet of pinto beans (Shorey \& Hale, 1965). The aphids were collected periodically from a Cotoneaster acutifolius (Hort.) hedge in Montreal $\left(73^{\circ} 39^{\prime} \mathrm{W} ; 45^{\circ} 30^{\prime} \mathrm{N}\right)$, Quebec. Third instar Aphis pomi were selected for the experiments. Coccinella septempunctata adults were collected in strawberry (Fragaria $\mathrm{x}$ ananassa Duch.) fields in the Saint-Jean-surRichelieu ( $\left.73^{\circ} 15^{\prime} 00^{\prime \prime} \mathrm{W} ; 4^{\circ} 18^{\prime} 58^{\prime \prime} \mathrm{N}\right)$ area (Quebec, Canada). A population of Harmonia axyridis of Chinese origin was reared on Ephestia kuehniella Zeller (Lepidoptera: Pyralidae) eggs. Both predators were reared for at least two weeks on a diet composed of several species of aphids (mainly Aphis citricola, excluding A. pomi), a $20 \%$ sucrose solution and wild flower pollen. They were starved $24 \mathrm{~h}$ before the experiments.

Experimental design. The experiment was done at $23^{\circ} \mathrm{C}( \pm$ $\left.1^{\circ} \mathrm{C}\right), 16 \mathrm{~L}: 8 \mathrm{D}$, and $60 \% \mathrm{RH}$. The experimental setup consisted of two 15-cm-diameter plastic pots fitted one within the other (Lucas et al., 1997). The upper pot (8 cm high) contained an apple tree sapling (Malus domestica Borkhausen; cultivar Empire; 5-7 weeks old; five leaves), whose roots were soaked in water contained in the lower pot $(15 \mathrm{~cm}$ high). The prey and the predators were deposited on the leaves and were allowed to settle for 15 minutes. They were observed through a plastic film enclosing the upper pot.

Each species of predator (C. septempunctata and $H$. axyridis unsexed adults) was subjected to the following treatments: 1) 30 first instar C. rosaceana ("leafroller treatment"), 2) 100 third instar A. pomi ("aphid treatment"), or 3) 30 first instar $C$. rosaceana and 100 third instar $A$. pomi ("two-prey treatment"). Such densities are frequently observed in field situations (C. Vincent pers. com.). Preliminary tests showed that the number of prey offered substantially exceeded the number of prey that the predators could eat daily. Thirty replicates of each treatment and 30 of control treatments (no predators) were carried out. After $24 \mathrm{~h}$ the voracity of the predators was assessed as the number and biomass of preys consumed.
Data analysis. The number of prey consumed was corrected by subtracting the mean mortality in the controls from the mortality observed in each of the experimental setups containing a predator. To estimate the ingested biomass, the mean weights of first instar C. rosaceana $(0.498 \mathrm{mg} ; \mathrm{n}=50)$ and of third instar A. pomi $(0.147 \mathrm{mg} ; \mathrm{n}=200)$ were determined; first instar $C$. rosaceana eaten were approximately three times heavier than $A$. pomi nymphs. The overall predator voracity (both prey species pooled) was compared using a two-way analysis of variance (ANOVA; factors: predator and prey treatments) performed with SuperANOVA ${ }^{\circledR}$ (Abacus Concepts, 1989) and followed, when appropriate, by Fisher's Protected LSD tests. The overall number of prey eaten and the overall biomass consumed were analyzed.

To evaluate the effect of the presence of a second prey species, the number of individuals of $A$. pomi eaten and the biomass consumed, when one or two prey species were present, were compared using a two-way ANOVA. The number of individuals of $C$. rosaceana eaten and the biomass consumed were evaluated similarly for $A$. pomi.

\section{RESULTS}

Overall predator voracity (both prey species pooled). $H$. axyridis was more voracious than $C$. septempunctata $\left(F_{1,160}=26.4, p<0.0001\right)$, eating a total of 40.8 $( \pm 3.4$; mean $\pm \mathrm{SE})$ and $27.3( \pm 3.0)$ prey in $24 \mathrm{~h}$, respectively. The biomass consumed by $H$. axyridis $(8.64 \mathrm{mg})$ in $24 \mathrm{~h}$ was also significantly greater than the biomass consumed by $C$. septempunctata $(5.22 \mathrm{mg})\left(F_{1,164}=53.4\right.$, $p<0.0001)$. The interaction term (prey x predator) of the two-way ANOVAs was significant for both the number of prey eaten $\left(F_{2}=6.0, p=0.0032\right)$ and the biomass consumed $\left(F_{2}=10.3, p<0.0001\right)$. Each predator species was analyzed separately using a one-way ANOVA.

With all prey species pooled, C. septempunctata ate significantly more individuals when both prey were present than when only one species was available $\left(F_{2,81}=\right.$ 67.9, $p<0.0001)$ (Fig. 1A). Similar results were obtained with $H$. axyridis $\left(F_{2,79}=242.7, p<0.0001\right)$. Both predators ate significantly more $A$. pomi than $C$. rosaceana in the single-prey treatments (C. septempunctata: (LSD, $p<$ $0.0002) ; H$. axyridis: (LSD, $p<0.0017$ ). The total biomass consumed by $C$. septempunctata, $10.1 \mathrm{mg}$ (prey species pooled), was also significantly greater in two-choice than in single-prey treatments $\left(F_{2,81}=62.5, p<0.0001\right)$ (Fig. 1B). H. axyridis exhibited the same response, consuming an average of $14.0 \mathrm{mg}$ in two-prey treatments $\left(F_{2,79}=112.1, p<0.0001\right)$. In the single-prey treatments, the biomass of $A$. pomi and $C$. rosaceana consumed by $C$. septempunctata was similar (LSD, $p<0.1620$ ), although $H$. axyridis ate more $C$. rosaceana than aphids (LSD, $p<$ $0.0001)$.

Prey-specific predator voracity. $H$. axyridis was more voracious than $C$. septempunctata on $A$. pomi $\left(F_{1,105}=\right.$ $11.7, p=0.0009)$, eating respectively, $49.5( \pm 3.5)$ and $37.1( \pm 3.4)$ individuals in $24 \mathrm{~h}$. The same results were observed for C. rosaceana $\left(F_{1,112}=58.1, p<0.0001\right), H$. axyridis eating $10.9( \pm 0.8)$ and C. septempunctata $4.9( \pm$ $0.5)$ individuals. Because the interaction term of the two-way ANOVA (prey $\times$ predator) was significant when analyzing predation on $A$. pomi $\left(F_{1}=6.6, p=0.0116\right)$ 

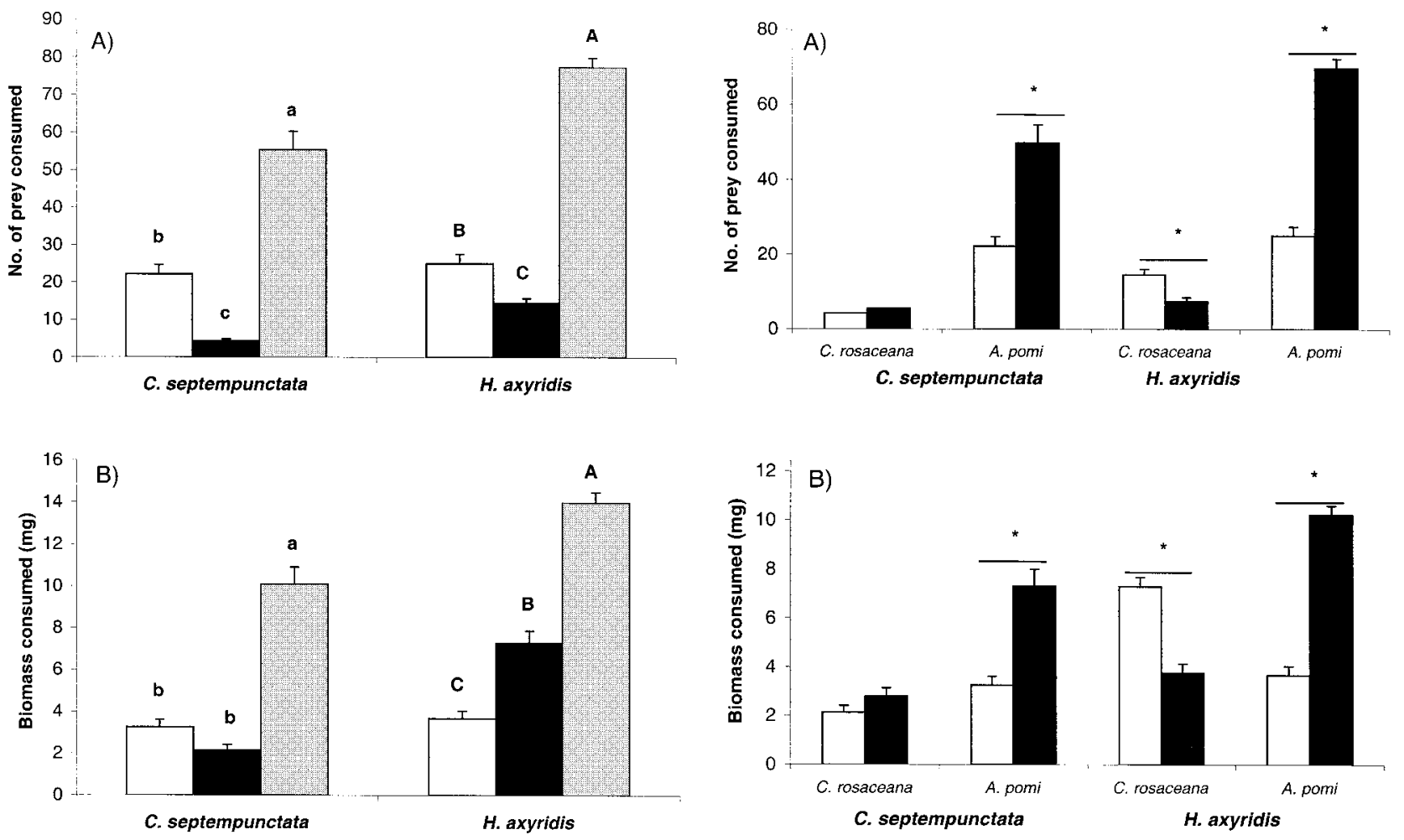

Fig. 1. Overall predator voracity (Mean + SE), by Coccinella septempunctata and Harmonia axyridis in $24 \mathrm{~h}$, when offered Aphis pomi (white bars), Choristoneura rosaceana (black bars) or both prey species (grey bars). A - total number of prey predated; B - total biomass consumed. Different letters indicate a significant $(p<0.05)$ difference among the different treatments for the same coccinellid species.

and on C. rosaceana $\left(F_{1}=27.1, p<0.0001\right)$, predator treatments (species) were analyzed separately using one-way ANOVA.

In two-prey treatments, $C$. septempunctata ate significantly more $A$. pomi than in single-prey treatments $\left(F_{1,52}=\right.$ 24.0, $p<0.0001$ ) (Fig. 2A). H. axyridis also ate more aphids in the presence of a second prey species $\left(F_{1,53}=\right.$ $153.8, p<0.0001)$. In contrast, the voracity of $C$. septempunctata on $C$. rosaceana did not increase when aphids were present $\left(F_{1,57}=2.1, p=0.1493\right)$, although the voracity of $H$. axyridis decreased significantly in the presence of aphids $\left(F_{1,55}=27.3, p<0.0001\right)$. Similar results were observed for the biomass eaten (Fig. 2B).

\section{DISCUSSION}

Our experiments support three main conclusions. First, the overall voracity (prey pooled) of both predators increased when the two prey species were present. This result may be attributed to a functional response effect (Holling, 1966). An interesting question to test would be whether the simultaneous presence of both prey species also generates a numerical response effect, both reproductive and aggregative. Such an effect may increase the overall impact of predators on pest populations.

Second, both coccinellids showed a feeding preference for the aphid over the lepidopteran larva. In the two-prey treatments, $C$. septempunctata and $H$. axyridis ate both $C$.

Fig. 2. Prey-specific predator voracity (Mean $+\mathrm{SE}$ ), of Coccinella septempunctata and Harmonia axyridis in $24 \mathrm{~h}$ for Choristoneura rosaceana and Aphis pomi, when offered one (white bars) or two (black bars) prey species. A - number of prey predated; B - biomass consumed. Asterisks indicate a significant ( $p$ $<0.05$ ) difference the single and the two-prey treatments.

rosaceana and $A$. pomi. However, they ate at least twice as many $A$. pomi than $C$. rosaceana in terms of both numbers of individuals and biomass consumed. In a previous study, $C$. septempunctata and $H$. axyridis also displayed a significant preference for the aphid $A$. citricola over the spider mite $T$. urticae at three different prey-ratios (Lucas et al., 1997). Mohan et al. (1991) also showed that C. septempunctata had a similar feeding preference for the aphid Rhopalosiphum maidis Fitch compared with Chilo partellus Swinhoe (Lepidoptera: Pyralidae) larvae. In 6 h, predation of $C$. partellus by $C$. septempunctata decreased significantly when both prey species were present, whereas predation of $R$. maidis remained constant whether C. partellus were present or not (Mohan et al., 1991). Our results confirm the preference for aphids as prey for both coccinellid species.

Third, the addition of a second prey in the system had contrasting consequences on aphids and lepidopteran larvae. For $C$. rosaceana, the addition of aphids to the system did not significantly increase the number of individuals eaten and the biomass of Lepidoptera consumed by $C$. septempunctata. However, the predation of $C$. rosaceana by $H$. axyridis decreased significantly in the presence of aphids. These results confirmed the feeding preference of both predators for aphids and showed clearly the limitations upon the efficacy of both coccinellids against lepidopteran larvae. 
In contrast, the number of individuals eaten and the biomass of aphids consumed increased consistently when the second prey species was present. For the aphid, despite the fact that the second prey species differed from the first, the voracity of both predators increased as a functional response effect (Holling, 1966), meaning that the presence of an alternative (non-preferred) prey with a preferred one may generate a functional response effect toward the preferred prey, but not toward the alternative one.

It is difficult to predict what may occur in the field when both (or more) prey species are present at the same time. The outcome will depend on factors such as the priority of establishment, the spatial distribution of both prey (at plant and micro-habitat level), the presence of a third (or further) prey species, the relative densities of the different species, the feeding preferences of other predators. Our results suggest that apparent competition should be expected. Apparent competition is an indirect effect which occurs when two prey species share a common predator. An increase in the population of the first prey species, generates an increase in the predator population, causing a subsequent decrease in the population of the second prey species (Holt \& Lawton, 1994; Wooton, 1994). Adding lepidopteran larvae may increase $H$. axyridis (but not $C$. septempunctata) pressure on aphids (both through numerical and functional responses). In contrast, adding aphids may decrease the predation pressure (by both predators) on lepidopteran larvae. However, we should be cautious in such a conclusion because a great number of other prey species have been identified as pests of apple orchards in North America (Oatman et al., 1964; Vincent \& Bostanian, 1988; Chouinard et al., 2000). A great number of predator species attack aphids and other pests (for example more than 10 coccinellid species are found in Quebec apple orchards) and may complicate the situation (Tourneur et al., 1992).

The number of aphids consumed is probably overestimated by our experiments because, in general, many individuals leave the host plant when attacked by a predator. Minoretti \& Weisser (2000) observed that when C. septempunctata attacked a colony of 30 Acyrthosiphon pisum aphids, about $45 \%$ of the prey left and $45 \%$ stayed on the plant. Lucas et al. (2002) observed that, after $24 \mathrm{~h}, 18 \%$ of the Aphis citricola individuals (100 individuals) had left the apple sapling in the presence of $H$. axyridis and $19 \%$ in the presence of $C$. septempunctata. This could mean that the proportion of preferred/non-preferred prey might change very rapidly on a crop plant. Accordingly, the predator may switch to a non-preferred prey present on the plant or decide to leave. This fact might influence predator efficacy against the leafroller, likely by decreasing its consumption. Moreover, it was observed that $C$. septempunctata visited an aphid colony of 30 aphids for a short time (on average $80 \mathrm{~min}$.) (Minoretti \& Weisser, 2000).

Our results and those of previous studies (Lucas et al., $1997,1998 b, 2002)$ confirm the higher voracity and efficacy of $H$. axyridis over $C$. septempunctata as a predator of pests in apple orchards. Before consideration of $H$. axyridis as a sound biocontrol agent, however, the impact of the establishment of this coccinellid in Canadian apple orchards must be examined thoroughly because $H$. axyridis may affect pest populations directly by predation and indirectly by interacting with local coccinellids and other aphidophagous species via competition and intraguild predation (Evans, 1991; Hironori \& Katsuhiro, 1997; Lucas et al., 1998a, 2002).

ACKNOWLEDGEMENTS. We thank N. Dauphinais and B. Rancourt for technical assistance, and an anonymous reviewer for commenting the manuscript. This research was supported by grants from NSRC and FCAR (Quebec) to D. Coderre and by scholarship from the Programme d'Aide Financière à la Recherche et à la Création (PAFARC) of the Université du Québec à Montréal to $\mathrm{S}$. Demougeot. This is contribution 335/2003.06.02R from the Horticultural Research and Development Centre, Agriculture and Agri-Food Canada, Saint-Jean-sur Richelieu, Québec, Canada.

\section{REFERENCES}

Abacus Concepts 1989: SuperANOVA User's Guide, 1.1. Calabasas, California: BrainPower Inc.

Carroll D.P. \& Hoyt S.C. 1984: Hosts and habitats of parasitoids (Hymenoptera: Aphidiidae) implicated in biological control of Apple Aphid (Homoptera: Aphididae). Environ. Entomol. 15: 1171-1178.

Carrière Y., Deland J.P., Roff D.A. \& Vincent C. 1994: Life history costs associated with the evolution of insecticide resistance. Proc. R. Soc. Lond. B Biol. Sci. 258: 35-40.

Chapin J.B.V. \& Brou A. 1991: Harmonia axyridis (Pallas), the third species of the genus to be found in the United States (Coleoptera: Coccinellidae). Proc. Entomol. Soc. Wash. 93: 630-635.

Chapman P.J. \& Lienk S.E. 1971: Tortricid Fauna of Apple in New York. NY State Agric. Exp. Station, Cornell Univ., Geneva, NY, 122 pp.

Chouinard G., Firlej A., Vanoosthuyse F. \& Vincent C. 2000: Guide d'Identification des Ravageurs du Pommier et de leurs Ennemis Naturels. Conseil des Productions végétales du Québec, Québec, Qc, 69 p.

Coderre D., Lucas E. \& Gagné I. 1995: The occurrence of Harmonia axyridis (Pallas) (Coleoptera: Coccinellidae) in Canada. Can. Entomol. 127: 609-611.

Dixon A.F.G. 1985: Structure of aphid populations. Annu. Rev. Entomol. 30: 155-174.

Evans E.W. 1991: Intra versus interspecific interactions of ladybeetles (Coleoptera: Coccinellidae) attacking aphids. Oecologia 87: 401-408.

HiRonori Y. \& Katsuhiro S. 1997: Cannibalism and interspecific predation in two predatory ladybirds in relation to prey abundance in the field. Entomophaga 42: 153-163.

HoDEK I. 1996: Food relationships. In: Hodek I. \& Honek A. (eds): Ecology of Coccinellidae. Kluwer Academic Publishers. Boston, pp. 143-238.

Holling C.S. 1966: The functional response of invertebrate predators to prey density. Mem. Entomol. Soc. Can. 48: 1-86.

Holt R.D. \& Lawton J.H. 1994: The ecological consequences of shared natural enemies. Annu. Rev. Ecol. Syst. 25: 495-520.

HorN D.J. 1991: Potential impact of Coccinella septempunctata on endangered Lycaenidae (Lepidoptera) in Northwestern Ohio, USA. In: Polgàr L., Chambers R.J., Dixon A.F.G. \& Hodek I. (eds): Behaviour and Impact of Aphidophaga. SPB 
Academic Publishing. The Hague, The Netherlands, pp. $159-162$.

Hukusima S. \& Kamei M. 1970: Effects of various species of aphids as food on development, fecundity and longevity of Harmonia axyridis Pallas (Coleoptera: Coccinellidae). Res. Bull. Fac. Agric. Gifu Univ. 29: 53-66.

IABlokoff-Khnzorian S.M. 1982: Les Coccinelles: ColéoptèresCoccinellidae. Société Nouvelle des Éditions Boubée, Paris, France, $568 \mathrm{pp}$.

Kareiva P. 1987: Habitat fragmentation and the stability of predator-prey interactions. Nature 326: 388-390.

Kring T.G., Gilstrap F.E. \& Michels G.J. Jr. 1985: Role of indigenous coccinellids in regulating greenbugs (Homoptera: Aphididae) on Texas grain sorghum. J. Econ. Entomol. 78 269-273.

LuCAs E., Coderre D. \& Brodeur J. 1998a: Intraguild predation among aphid predators: characterization and influence of extraguild prey density. Ecology 79: 1084-1092.

Lucas E., Coderre D. \& Vincent C. 1997: Voracity and feeding preferences of two aphidophagous coccinellids on Aphis citricola and Tetranychus urticae. Entomol. Exp. Appl. 85: $151-159$.

Lucas E., Gagné I. \& Coderre D. 2002: Impact of Harmonia axyridis on adults Coccinella septempunctata and Coleomegilla maculata (Coleoptera: Coccinellidae). Eur. J. Entomol. 99: 457-463.

Lucas E., Lapalme S. \& Coderre D. 1998b: Voracité comparative de trois coccinelles aphidiphages sur le tétranyque rouge du pommier (Acarina: Tetranychidae). Phytoprotection 78: $117-123$.

Maredia K.M., Gage S.H., Landis D.A. \& Wirth T.M. 1992: Ecological observations on predatory Coccinellidae (Coleoptera) in Southwestern Michigan. Great Lakes Entomol. 25: 265-270.

Minoretti N. \& Weisser W.W. 2000: The impact of individual ladybirds (Coccinella septempunctata, Coleoptera: Coccinellidae) on aphid colonies. Eur. J. Entomol. 97: 475-479.

Mohan B.R., Verma A.N. \& Singh S.P. 1991: Predators of Chilo partellus (Swin.) infesting forage sorghum at Hisar. $J$. Insect Sci. 4: 41-44.
Murdoch W.W. \& Marks J.R. 1973: Predation by coccinellid beetles: Experiments on switching. Ecology 54: 160-167.

OAtman E.R., Legner E.F. \& Brooks R.F. 1964: An ecological study of arthropod population in northeastern Wisconsin: insect species present. J. Econ. Entomol. 57: 978-983.

Ongagna P., Giuge L., Iperti G. \& Ferran A. 1993: Life cycle of Harmonia axyridis (Col.: Coccinellidae) in its area of introduction: South-Eastern France. Entomophaga 38: 125-128.

Pree D.J., Whitty K.J., Pogoda M.K. \& Bittner L.A. 2001: Occurrence of resistance to insecticides in populations of the obliquebanded leafroller, from orchards in Southern Ontario. Can. Entomol. 133: 93-103.

ReISSIG W.H. 1978: Biology and control of the obliquebanded leafroller on apples. J. Econ. Entomol. 71: 804-809.

Reissig W.H., Stanley B.H. \& Hebding H.E. 1986: Azinphosmethyl resistance and weight-related response of obliquebanded leafroller (Lepidoptera: Tortricidae) larvae to insecticides. J. Econ. Entomol. 79: 329-333.

Shorey H.H. \& HALE R.C. 1965: Mass rearing of the larvae of nine noctuid species on a simple artificial medium. J. Econ. Entomol. 58: 522-524.

Smirle M.J., Vincent C., Zurowski C. \& Rancourt B. 1998: Azinphosmethyl resistance in the obliquebanded leafroller, Choristoneura rosaceana: reversion in the absence of selection and relationship to detoxication enzyme activity. Pestic. Biochem. Physiol. 61: 183-189.

Tedders W.L. \& Schaefer P.W. 1994: Release and establishment of Harmonia axyridis (Coleoptera: Coccinellidae) in the United States. Entomol. News 105: 228-243.

Tourneur J.C., Bouchard D. \& Pilon J.G. 1992: Le complexe des ennemis naturels des pucerons en pommeraie au Québec. In: Vincent C. \& Coderre D. (eds): La Lutte Biologique. Gaëtan Morin, Boucherville, Québec, Canada, pp. 179-194.

Vincent C. \& Bostanian N. 1988: La protection des vergers de pommiers au Québec: état de la question. Natur. Can. 115: 261-276.

Wooton J.T. 1994: The nature and consequences of indirect effects in ecological communities. Annu. Rev. Ecol. System. 25: $443-466$.

Received June 17, 2002; revised May 28, 2003; accepted October 10, 2003 